\title{
Paleogene phreatomagmatic volcanism on the western main fault of the northern Upper Rhine Graben (Kisselwörth diatreme and Nierstein-Astheim Volcanic System, Germany)
}

\author{
Herbert Lutz • Volker Lorenz • Thomas Engel • \\ Friedrich Häfner • Jost Haneke
}

Received: 10 December 2012 / Accepted: 10 June 2013 / Published online: 5 July 2013

(C) The Author(s) 2013. This article is published with open access at Springerlink.com

\begin{abstract}
At the western margin of the northern Upper Rhine Graben, Germany, six deeply eroded vents make up the Nierstein-Astheim Volcanic System. Among these vents the phreatomagmatic Kisselwörth maar-diatreme volcano erupted directly on, or at least very close to, the western main fault of the Upper Rhine Graben, which is still active today. This sheds new light on the early formation of one of the most conspicuous grabens of the European Cenozoic Rift System: While the oldest sediments within the northern end of the graben were biostratigraphically dated to Late Eocene/Early Oligocene (36-33 Ma), the Kisselwörth maar-diatreme was 40Ar/39Ar dated to $55.8 \pm 0.2 \mathrm{Ma}$. Thus, c. 20 million years before subsidence started the western main graben fault not only provided a path for rising magma but was also hydraulically active to allow phreatomagmatic eruptions.
\end{abstract}

Keywords Phreatomagmatic volcanism · Diatreme ·

Paleogene · Upper Rhine Graben · Nierstein Horst

Editorial responsibility: K. Németh, Guest Editor

This paper constitutes part of a topical collection:

Smith IEM, Nemeth K, and Ross P-S (eds) Monogenetic volcanism and its relevance to the evolution of volcanic fields.

H. Lutz $(\bowtie) \cdot$ T. Engel

Naturhistorisches Museum Mainz/Landessammlung für

Naturkunde Rheinland-Pfalz, Reichklarastrasse 10, 55116 Mainz,

Germany

e-mail: dr.herbert.lutz@stadt.mainz.de

V. Lorenz

Physikalisch Vulkanologisches Labor, Universität Würzburg,

Pleicherwall 1, 97070 Würzburg, Germany

F. Häfner · J. Haneke

Landesamt für Geologie und Bergbau Rheinland-Pfalz,

Emy-Roeder-Straße 5, 55129 Mainz, Germany

\section{Introduction}

In the European Cenozoic Rift System most rifts are associated with intensive volcanic activity (e.g. Dèzes et al. 2004; Dürr and Grimm 2011). Among these rifts the Upper Rhine Graben (URG) in south-western Germany is the morphologically most conspicuous (Fig. 1a) and presumably best studied example. Especially at its northern end, where this Cenozoic graben is superimposed on the Permocarboniferous Saar-Nahe Basin, a WSW-ENE trending Late Variscan intermontane half graben containing thick Rotliegend sediments which formed by intensive crustal extension during the Late Variscan orogeny (Lorenz and Haneke 2004; von Seckendorff et al. 2004; Boy et al. 2012) (Fig. 1b), a considerable number of small Tertiary volcanoes has been recorded (e.g. Anderle 1974; Reischmann et al. 2011). These are located along the northern margin of the URG, i.e. in the Taunus Mountains of the Hunsrück-Taunus Mountain Range (HTMR) but also on the eastern shoulder of the northern URG, i.e. on the Sprendlingen Horst (SH) with its Rotliegend (Lower Permian) sediments and volcanics (e.g. Anderle 1974; Boy et al. 2012). A number of Tertiary volcanoes have also been recorded from the northern and north-eastern part of the Odenwald Mountains (O, for abbreviations comp. Fig. 1) and the adjacent north-western part of the Spessart Mountains (S; e.g. Lorenz et al. 2010). In contrast, up to now only a few monogenetic volcanoes have been described from the western shoulder of the URG, i.e. within the Mainz Basin (MzB) and, towards the south, along the eastern cuesta of the Pfälzer Wald (PW; e.g. Negendank 1969a, b, Negendank 1975; Horn et al. 1972; Schäfer 2012). Some sparse volcanic activity occurred already in the Late Cretaceous (c. 70-68 Ma) with presumed genetic relationships to the URG and volcanoes aligned along the eastern shoulder of the northern URG from the Kraichgau $(\mathrm{K})$ in the south to the eastern Taunus and western Spessart Mountains in the north (e.g. Anderle 1974; Frenzel 1955, 


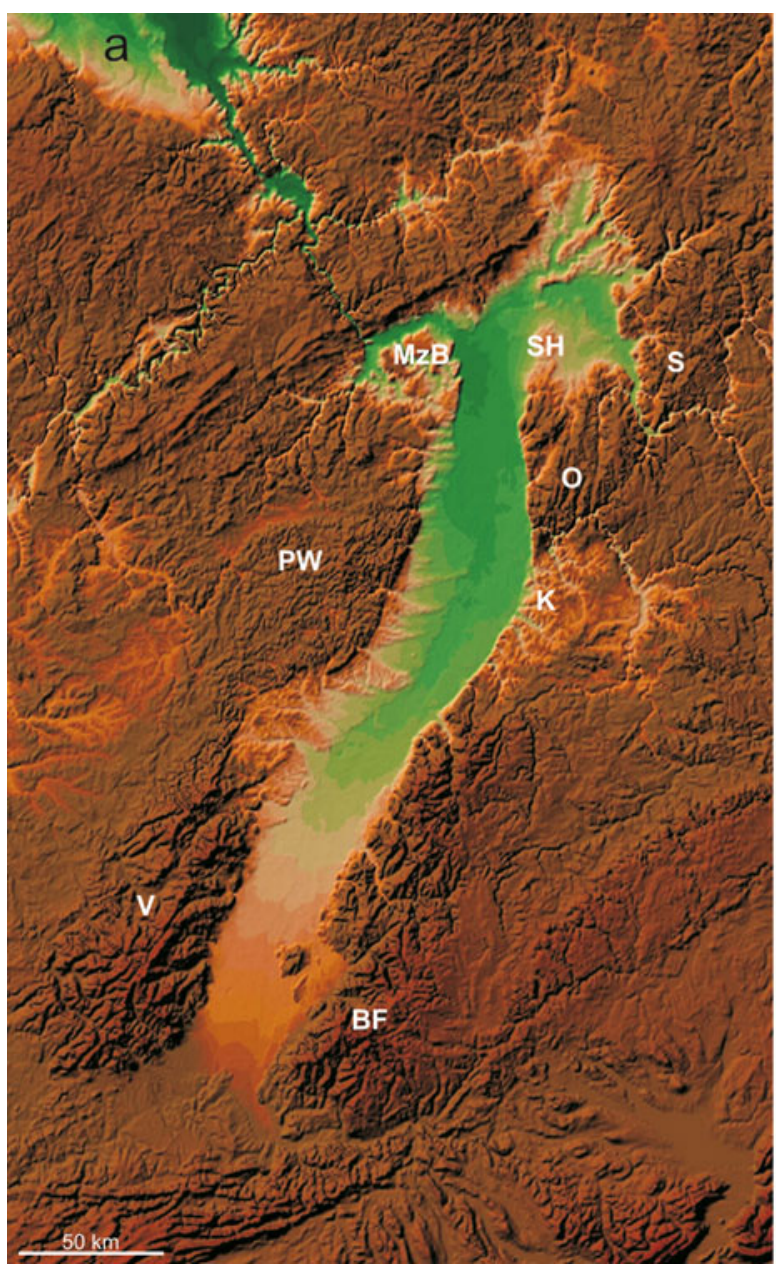

Fig. 1 Topography (a) and geology (b) of the Upper Rhine Graben $(U R G)$, SW Germany. Encircled are the URG, the WSW-ENE trending Late Variscan Saar-Nahe Basin (Rotliegend trough; $S N B$ ), and the Hunsrück-Taunus Mountain Range (HTMR) (b). Additional abbreviations (a): MzB Mainz

Frenzel 1975; Lippolt et al. 1975; Schweizer and Kraatz 1982; Lorenz et al. 2010). This Early Tertiary volcanism shows several main phases of activity (61-55 Ma, 52-47 Ma, 44-39 Ma and 37-35 Ma) with a climax in the Middle Eocene (49-47 Ma; e.g. Horn et al. 1972; Lippolt et al. 1974, Lippolt et al. 1975; Keller et al. 2002; Derer et al. 2005; Schmitt et al. 2007; Reischmann et al. 2011). According to Fekiacova et al. (2007) volcanic activity ranges from c. 59-47 Ma along the northern end of the URG and from c. 51-48 Ma in the Mainz Basin while it culminated c. 49-47 Ma on the Sprendlingen Horst and in the northern Odenwald Mountains.

During unusual periods of extreme low water of the River Rhine, like in May and November 2011, we could sample and study pyroclastic rocks cropping out in the river bed between the communities of Nackenheim and Nierstein, c. $12 \mathrm{~km} \mathrm{SSE}$ of the city of Mainz. In those months the lapilli tuff cropped out at the left banks of the river near the southern tip of Kisselwörth Island (centre, 49 $54^{\prime} 06.22^{\prime \prime}$ N, 8 ${ }^{\circ} 20^{\prime} 47.94^{\prime \prime} \mathrm{E}$, c. $82 \mathrm{~m}$ a.s.l.). The area of the almost continuous tuff outcrop is

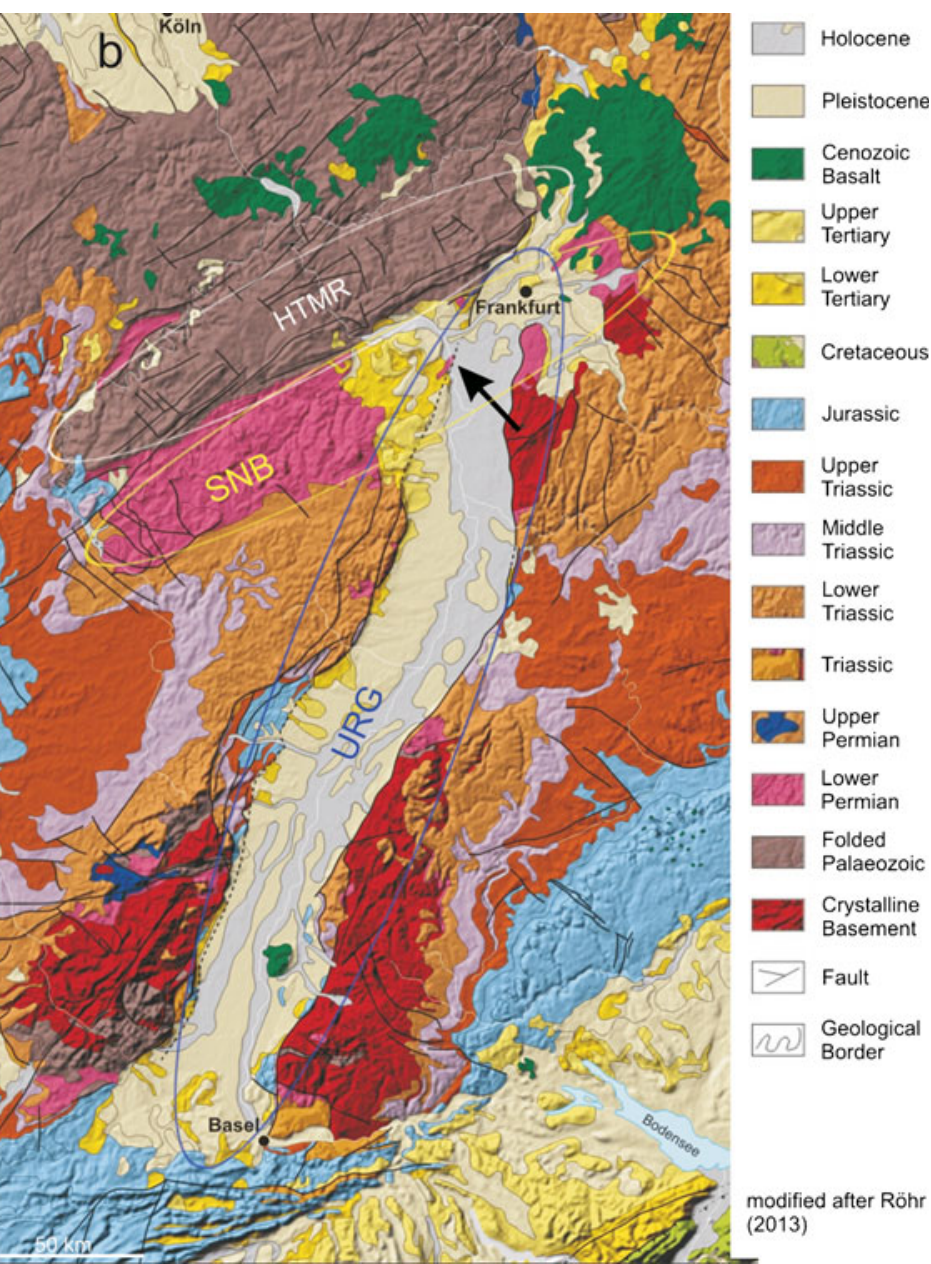

Basin, $S H$ Sprendlingen Horst, $O$ Odenwald Mountains, $S$ Spessart Mountains, $P W$ Pfälzer Wald Mountains, $K$ Kraichgau, $V$ Vosges Mountains, $B F$ Black Forest Mountains. The arrow points at the Kisselwörth diatreme (modified after Röhr 2013)

circular in shape, surrounded by Lower Permian (Rotliegend) sediments, has a diameter of approximately $150 \mathrm{~m}$ (Fig. 2) and, therefore, can be considered as a diatreme. According to Reischmann et al. $(2011,17)$ the Kisselwörth volcano [placed by him on the southern tip of the nearby Nonnenau Island] erupted exactly on the western main fault of the URG. This western main fault cannot be considered as one single fault but rather as a narrow fault zone which, in this region, has not yet been located exactly by drill holes since it runs beneath the main river bed (Fig. 3a). Recently, Schäfer (2012) also mentions a Tertiary volcano in the bed of the River Rhine near Nackenheim, however, without going into details.

To our knowledge, the Kisselwörth diatreme has been sampled for the first time by Karl Stapf, Mainz, in 1985. However, his specimen which is now kept in the Naturhistorisches Museum Mainz/Landessammlung für Naturkunde RheinlandPfalz (MNHM G 2011/131-LS) was labelled as "basalt" and has never been studied. In 2003, additional samples have been collected by the Geological Survey of Rhineland-Palatinate and 


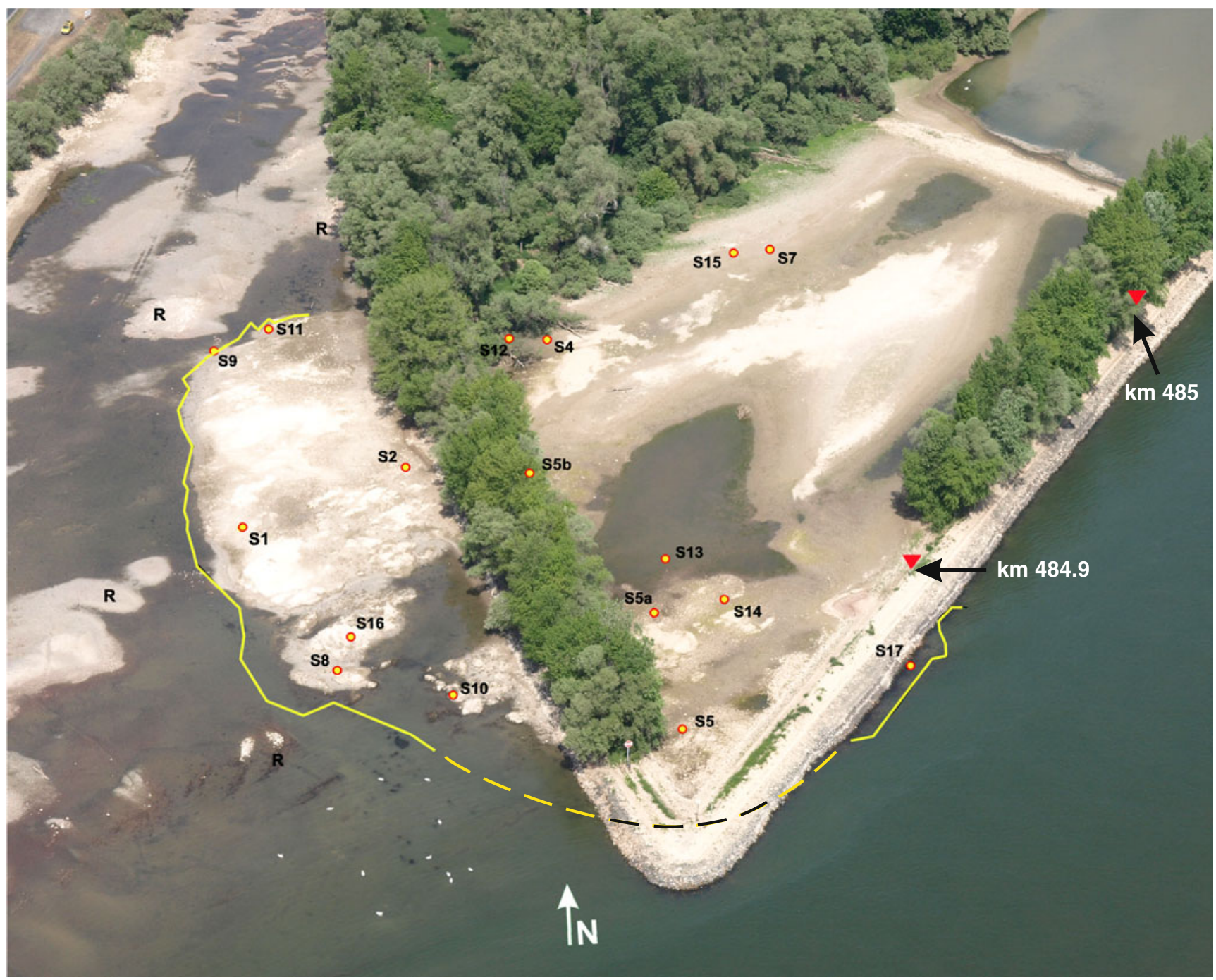

Fig. 2 Aerial photo of the southern tip of Kisselwörth Island with the diatreme at low water. The accessible margins of the diatreme (yellow line, dashed line: presumed continuation) and the sampling locations for diatreme tuff were mapped with a GPS receiver. $R$ Rotliegend country rock outcrops where joints have been measured. S1, S2, S3, etc.: sampling points (photo: Braun I, 09.05.2011) were briefly studied petrographically, but they have not been discussed in a regional geological context and remained unpublished.

\section{Materials and methods}

In May and November 2011, we sampled more than $150 \mathrm{~kg}$ of the Kisselwörth pyroclastic rocks at 12 different locations in the diatreme where they were not covered by recent river sediments or by embankment constructions (Fig. 2). The accessible margins of the diatreme and all sampling points were mapped with a GPS receiver (Garmin GPSmap 60CSx). We also measured 43 joints scattered all over the well-exposed western part of the diatreme (Fig. 3b) and 21 joints in the adjacent Rotliegend country rock (Fig. 3c). This was done with a geological compass (Freiberger Präzisionsmechanik) and a 3-m long batten.

Rock samples were cut with a diamond saw and smoothened by hand on sandpapers and then polished with grinding powders down to a grit of 800 . Photos were taken under water immersion using the digital camera Sony Nex 5. Thin sections were made with a Logitech PM4, digitally photographed with a Leica DFC 450 and finished with Leica Application Suite (LAS V.3.8). With respect to stratigraphic names and timescales we follow the monographs edited by the German Stratigraphic Commission (Deutsche Stratigraphische 2002, 2011, 2012).

Since the lapilli tuff within the maar-diatreme volcano contains amphibole phenocrysts $40 \mathrm{Ar} / 39 \mathrm{Ar}$ dating was done on one of these phenocrysts at the BGC Berkeley Geochronology 

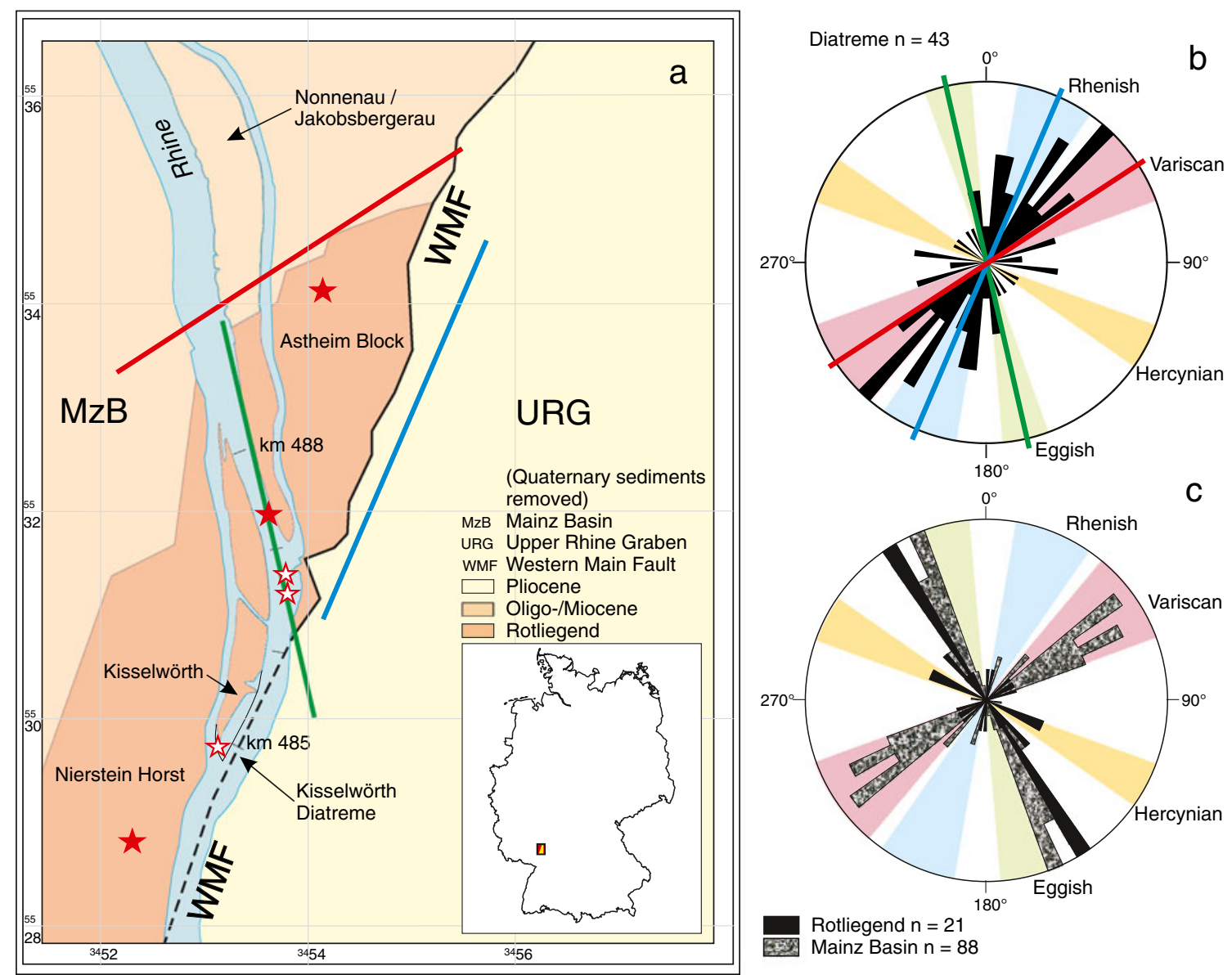

Fig. 3 a-c Geological map of the north-eastern part of the Nierstein Horst and the Astheim block (modified after Steuer et al. 1974) (a). Their south-eastern margin is marked by the western main fault (WMF) of the URG separating the URG from the Mainz Basin $(M z B)$. Volcanic vents are marked by red stars (filled "basalt"; open pyroclastics). Main tectonic directions are documented by coloured lines (Rhenish blue, Variscan red, Eggish green). b Joints within the Kisselwörth diatreme

Center. The measurement yielded an integrated age of $55.8 \pm 0.2$ (1 sigma; Mertz DF and Renne PR, personal communication).

\section{Petrography and lithology}

The horizontally transected diatreme shows differences in height a.s.l. of less than $1 \mathrm{~m}$. Nevertheless, the structure of the exposed ash lapilli tuff varies to some extent. Most of it appears as a rather dull greyish-brown, c. 1:1 mixture of juvenile and country rock clasts with pyroclasts of less than $1 \mathrm{~cm}$ in diameter. Larger clasts are present but rare (Fig. 4a). Subordinately also coarser types of lapilli tuff are exposed which contain larger clasts (diameters up to $5 \mathrm{~cm}$ ) of Permian sediments and juvenile volcanic rocks (Figs. 4b-d). In addition to other macroscopic and microscopic features, this heterolithic composition is an important aspect indicative for maar-diatreme volcanoes (see below). The observed differences in the macroscopic lapilli tuff predominantly show Rhenish (NNE/SSW), Variscan (NE/ SW) but also Eggish (NNW/SSE) directions. c Joints in the surrounding Rotliegend (Lower Permian) country rock show these directions only very subordinately whereas joints striking perpendicular to the Variscan, i.e. striking in the Hercynian direction, are dominating like in the adjacent Mainz Basin (cf. Falke 1960)

structure of the lapilli tuff most likely indicate some bedding within the diatreme. However, since large areas of the lapilli tuff are covered by clayey to silty layers of recent river sediments and algal mats, we cannot exclude, up to now, that these differences in structure might also indicate the presence of feeder conduits within the diatreme (mapping of these features is planned but since the Kisselwörth diatreme is part of a nature protected area this will require (1) the permission of the nature preservation authorities, (2) a long period with low water and (3) the application of machines like e.g. fire-fighting equipment for cleaning the surface from recent sediment and algae).

All lapilli tuff samples studied so far are matrix supported. The matrix is composed of juvenile ash grains and finely fragmented country rocks, i.e. silt and sand grains of Lower Permian age. First studies of the juvenile clasts revealed that these are tachylite and sideromelane lapilli (Fig. 5a, b). The sideromelane glass type represents an additional important hint for the phreatomagmatic origin of this lapilli tuff (see 


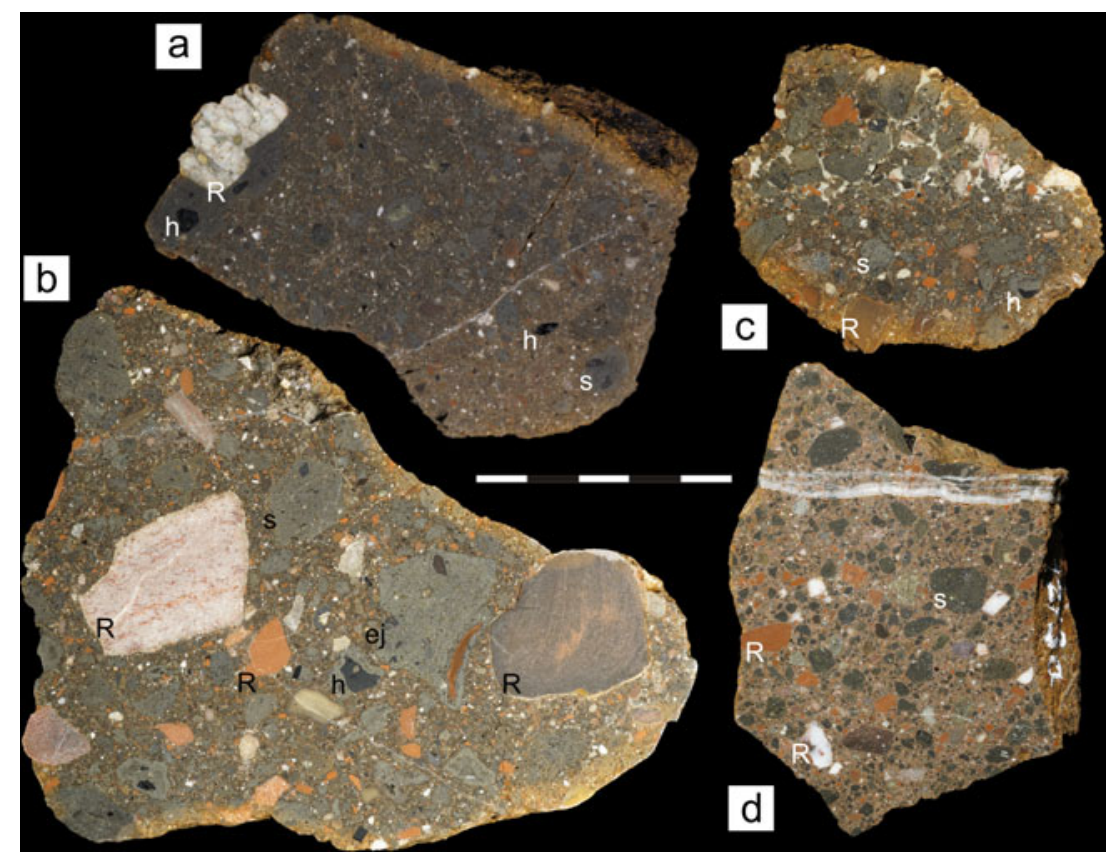

Fig. $4 a-d$ Variability of lapilli tuff in the Kisselwörth diatreme. $a$ Most common rather fine-grained type. MNHM G 2013/13b-LS, sampling point S2. $b-d$ Less common intermediate to coarse-grained types. $b$ Lapilli tuff with small spherical lapilli and larger sharply edged juvenile and Rotliegend clasts (MNHM G 2013/14a-LS, sampling point S10). $c$ Tuff showing weak bedding structure as indicated by a conspicuous linear accumulation of light carbonate cement (ankerite) (MNHM G 2013/15aLS, sampling point S10). $d$ More homogenous tuff with fissures healed with ankerite (MNHM G 2013/16a-LS, sampling point S12). $s$ spherical lapillus, ej sharply edged juvenile clast, $R$ Rotliegend clast (sand-, silt-, claystones, quarzite etc. from alluvial fan horizons), $h$ hornblende. Photos of polished sections were taken under water immersion below). The majority of these juvenile pyroclasts has a rather globular shape and thus represents "spherical lapilli" having diameters of mostly $<1 \mathrm{~cm}$. Others are angular and sharply edged like most of the country rock clasts. According to the

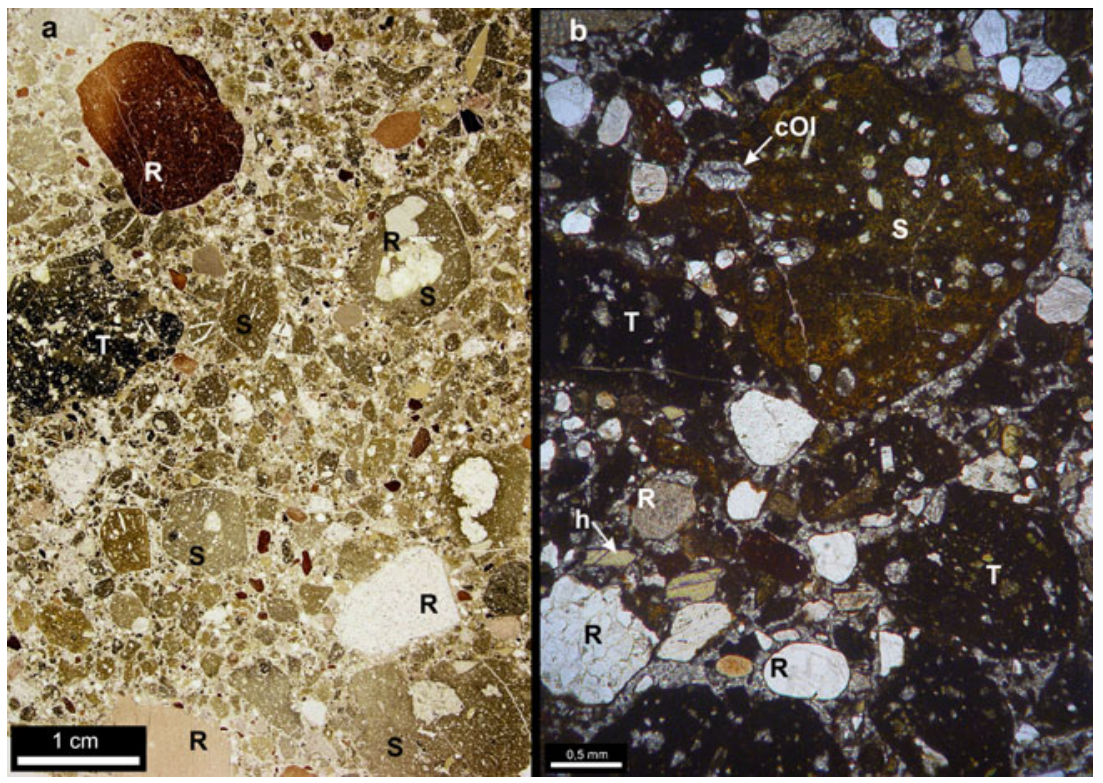

Fig. 5 a-b Thin section of a hand-specimen of phreatomagmatic lapilli tuff (a LGB thin section 23267, MNHM G 2013/17-LS, sampling point S9). Yellowish brown sideromelane lapilli are dominant. Lapilli range from low vesicularity to completely dense. Some include Rotliegend country rock clasts. Most of the light inclusions are quartz grains. b Thin section (LGB thin section 23200, sampling point S1) showing spherical opaque tachylite and yellowish brown sideromelane lapilli (plane light). The sideromelane lapillus includes a carbonate-replaced olivine phenocryst. $T$ tachylite, $S$ sideromelane, $\mathrm{cOl}$ carbonate-replaced olivine, $h$ hornblende, $R$ Rotliegend clasts and quartz grains (photos: Greller M) 
vesicularity index of Houghton and Wilson (1989), almost all are "non-vesicular" to at most "incipiently vesicular" $(<20 \%$ vesicles). Many of them have a core of either a hornblende (Pargasite) crystal (-fragment) or of a Permian country rock clast. We interpret the occurrence of Rotliegend sediment-xenoliths inside the juvenile lapilli as having been enclosed by magma in the root zone of the downward penetrating diatreme (Lorenz et al. 2002; Lorenz and Kurszlaukis 2007). Very frequently hornblende phenocrysts also occur isolated within the tuff matrix. The largest one noted has a surface of $45 \times 30 \mathrm{~mm}$. No xenoliths stemming from the mantle, from the lower crust or older than Permian have been observed. Country rock xenoliths only comprise fragments of red, orange, brown or green sand-, silt- and claystones of Lower Permian (Rotliegend) age and all observed clasts of crystalline rocks are stemming from Lower Permian alluvial fan horizons which originated from the nearby margin of the Variscan Saar-Nahe Basin. The country rock of the Kisselwörth diatreme is part of the Nierstein Formation, the local equivalent of the Standenbühl Formation, i.e. the top of preserved Lower Permian in this part of Germany (Boy et al. 2005, Boy et al. 2012; Schindler 2007). Upper Permian and Mesozoic sediments are missing. The latter fact agrees with observations made in many research drill holes and cores within the northern URG and the neighbouring Mainz Basin, where Tertiary sediments are lying unconformably on the Permian (cf. Pflug 1982) as it is also the case on the Sprendlingen Horst east of the northern URG.

The heterolithic composition of the lapilli tuff of the Kisselwörth diatreme (c. $50 \%$ of the pyroclastic rocks consist of country rock clasts), the occurrence of sideromelane lapilli as well as the lack of vesicles in the juvenile lapilli, respectively the occurrence of only incipient vesicularity in some juvenile lapilli, all these features jointly suggest that the diatreme can be considered to have been phreatomagmatic in origin.

\section{Tectonics and neighbouring volcanoes}

Tectonics along and within the URG have intensively been studied since decades (e.g. Illies and Fuchs 1974; Schmitt 1974a; Stapf 1988; Dürr and Grimm 2011). Nevertheless, it has remained unclear why the Rotliegend sediments of the Nierstein Horst c. $250 \mathrm{~m}$ to the west of the Kisselwörth diatreme continue towards the northeast into the Astheim Block which has been eroded intensively by the Rhine River and is covered by several meters of Pleistocene and Holocene Rhine sediments today (Schmitt and Meisl 1974). The north-western and south-eastern margins of this Astheim Block are well documented by a large number of boreholes (Schmitt 1974a) and show three major fault directions (Fig. 3a). Its south-eastern margin is defined as the western main fault of the URG and strikes in a Rhenish direction, i.e. NNE/SSW. The other faults show Variscan (NE-SW) and Eggish (NNW-SSE, 160-175²) directions. The same structural trends are also shown by the joints within the diatreme lapilli tuff (Fig. 4b). Though it is not the most prominent one within the diatreme, the Eggish direction is of special interest since "it shows a very characteristic connection with magmatic activities" (Richter-Bernburg 1974, 20), an observation which also applies to the region studied in this paper.

The joints in the surrounding country rock predominantly follow the Hercynian direction (NW-SE, 110-130 $)$ while the Variscan and Rhenish directions occur only subordinately (Fig. 4c). Hercynian faults are frequently observed in the Mainz Basin (Falke 1960) and are common in the adjacent Saar-Nahe Basin, where they are oriented perpendicular to its long axis (e.g. Schindler 2007). The maximum compressive component of the present regional stress field (Baumann and Illies 1983; Sass et al. 2011) corresponds with this Hercynian orientation of the joints in the Rotliegend country rocks. Despite the fact that in the Central European Volcanic Province Hercynian faults generally show the highest frequency being followed by Rhenish and Eggish directions (39, 24 and $23 \%$ : Richter-Bernburg 1974, 17), they are practically absent within the diatreme (Fig. 3b).

Thus, the joints within the lapilli tuff of the diatreme at the level of its actual transect reflect the regional tectonic development in a changing regional stress field since its consolidation. Since tuff within a diatreme subsides and alters diagenetically over millions of years (Suhr et al. 2006, 2012), it is likely that the joints measured developed long after the eruption of the Kisselwörth volcano. It seems that the Hercynian faults which are dominating in the surrounding regions had no influence on the formation of joints within the diatreme, i.e. these faults have possibly not been active within the last c. 35$55 \mathrm{Ma}$. The Variscan faults, however, are dominating the joint pattern in the lapilli tuff indicating that this direction plays an important role until today.

In addition, we can ascertain that the joints inside the diatreme do not result from syn- or posteruptive subsidence as one might have expected since this would have produced at least some radial and concentric joints, i.e. joints running parallel to the diatreme walls (Suhr et al. 2006, 2012).

There are five other vents associated with the Kisselwörth diatreme that have been discovered (Fig. 4a): Near its northern margin the Rotliegend sediments of the Astheim Block host a c. $90 \times 60 \mathrm{~m}$ large plug of nepheline-analcime-leucite-basanite composition (Schmitt and Meisl 1974, 32), trapezoidally elongated in an Eggish direction (NNW-SSE). It is covered by up to $4.4 \mathrm{~m}$ of Pleistocene and Holocene fluvial sand and gravel (Schmitt and Meisl 1974, 32). We assume that the emplacement of this plug followed the initial formation of a maar-diatreme volcano into which the plug could intrude in a second magmatic phase.

Three more vents have been found in 1957 and 1972-1973 during excavation activities to deepen the Rhine river bed. Unfortunately, of none of them we know the diameter. One of 
them, near the southern tip of the Nonnenau/Jakobsbergerau Island, has been described as an alkali-basaltic dyke or plug (Schmitt and Meisl 1974, 33) while the two others have been classified as strongly weathered basaltic rocks and were tentatively interpreted as melaphyre (Schmitt 1974b), i.e. a volcanic rock typical for the Lower Permian in the Saar-Nahe Basin. Unfortunately, no further details are known about these outcrops. In contrast to Schmitt's assumption that these tuff outcrops could be weathered Permian melaphyre we consider that they are most likely of Tertiary age, too. Our reason is that no volcanic activity has been recorded so far for the Late Rotliegend. During formation of the Saar-Nahe Basin volcanic activity is only known from the volcanic syn-rift stage, i.e. the Lower Permian Donnersberg-Formation (e.g. Lorenz and Haneke 2004). The top of the Donnersberg Formation in drillhole Olm 1 (c. $11.7 \mathrm{~km}$ WNW of the Kisselwörth diatreme) lies 1,284 $\mathrm{m}$ beneath sediments which tentatively have been interpreted as the Nierstein Formation. On the other hand, basaltic dykes and vents of Tertiary age are known to occur within the Rotliegend (and other) country rocks of different stratigraphic position at many places around the URG (Anderle 1974; Liebig and Gruber 2002; Schindler 2007; Becker at al. 2012).

Taking all this into account, we consider volcanoes associated with the Kisselwörth diatreme on the Nierstein Horst and on the Astheim Block to be Tertiary in age. The two strongly weathered tuff outcrops in the river bed are interpreted as diatremes which together with the basalt plug are aligned along a NNW-SSE trending Eggish lineament. Therefore, we suppose that they have erupted on a fault which separates the Astheim Block from the Nierstein Horst. This fault has already been postulated and mapped by Stoltz (1909) but has not been shown on later maps. Like the western main fault also this fault is assumed to have been, at least partly, hydraulically active allowing for potential phreatomagmatic eruptions.

This fault would also allow understanding why Pleistocene and Holocene sediments of the Rhine River are covering the spur-like Astheim Block while the adjacent Rotliegend rocks of the Nierstein Horst form a steep cuesta. Both behaved in a tectonically different fashion. Since any lithostratigraphic information is missing it remains unclear how much the Astheim Block subsided with respect to the Nierstein Horst and/or how much the latter has been uplifted relative to the Astheim block.

Only $1.3 \mathrm{~km}$ southwest of Kisselwörth - on top of the Nierstein Horst (field name "Auf der Schmidt") — in the early nineteenth century basalt of Eocene age ("Limburgit" in Schmitt and Meisl 1974) associated with tuff (Noeggerath 1842; Ludwig 1864) had been quarried. This was dated to 47.51 Ma (Lippolt et al. 1974). This outcrop was abandoned and filled with waste in the late nineteenth century. Fortunately, an old vineyard was cleared in 2011 bringing to daylight a large number of basalt, tuff fragments and small boulders that subsequently have been sampled. Two different types of calcitic joint fillings (fibrous and sparry) were also sampled that compare well with those described by Noeggerath (1842, 360). Thus, all regional volcanic occurrences, where tuffs similar to the Kisselwörth diatreme have been found, point to phreatomagmatic activities, i.e. an explosive magma-groundwater interaction.

\section{Reconstruction of the Kisselwörth maar-diatreme volcano}

Today, the eroded diatreme has a diameter of c. $150 \mathrm{~m}$. Assuming an angle of $80^{\circ}$ for its inner walls (hard rocks), we obtain a depth of c. $425 \mathrm{~m}$ for the bottom of the cone-shaped diatreme. Assuming a wall angle of $75^{\circ}$, the diatreme would have had a depth of c. $280 \mathrm{~m}$, and with an angle of $85^{\circ}$ it might have reached c. $860 \mathrm{~m}$. Below the lower diatreme end the root zone could have extended downwards for another several tens to several hundred meters (Lorenz and Kurszlaukis 2007). The Nierstein Formation reaches at least $770 \mathrm{~m}$ in thickness whereas the Standenbühl Formation may be 1,500 to $1,700 \mathrm{~m}$ thick (Boy et al. 2005, 2012; Schindler 2007). Only 11.7 km WNW of Kisselwörth, the research drill hole Olm 1 did not reach the base of Rotliegend sediments (final depth, 3,069.2 m). Thus, the preserved Rotliegend has a thickness of more than $2,900 \mathrm{~m}$. Based on a correlation of the Olm 1 drill hole with four other drill holes located within the URG, a total thickness of 2,000 $3,000 \mathrm{~m}$ has been reconstructed for the Rotliegend in the studied area (Becker et al. 2012). This implies that the lower diatreme end and even its underlying root zone are located within Rotliegend country rocks as indicated by absence of accessory lithic clasts from older stratigraphic units.

We can estimate the size of the preserved parts of the Kisselwörth maar-diatreme volcano. But how much has been eroded from its upper levels since its formation remains uncertain. As the lapilli tuff contains only xenolithic clasts from Rotliegend sediments, these must have reached the syneruptive surface. Since there is no indication of an additional fault between the Kisselwörth diatreme and the Nierstein Horst cuesta, which is only c. $250 \mathrm{~m}$ to the west, the diatreme must have been eroded for at least the difference between its actual top at $82 \mathrm{~m}$ a.s.l. and the preserved top of the Nierstein Horst at $172 \mathrm{~m}$ a.s.l., i.e., by at least $90 \mathrm{~m}$. If we take the height of the Nierstein Horst in the SW near Hillesheim (230 m a.s.l. in a distance of $15.3 \mathrm{~km}$ ) or even further to the SW between GauHeppenheim and Hochborn (293 m a.s.l., distance, $22 \mathrm{~km}$ ) we can expect a post-eruptive erosion of at least $210 \mathrm{~m}$. However, we have to take into account that over this distance the horst is cut by several (Eggish) faults increasing this uncertainty of how many meters the syneruptive surface has been eroded during the last $55 \mathrm{Ma}$. Post-eruptive erosion took place during a first phase until subsidence started c. $35 \mathrm{Ma}$ ago. Since then 
the Nierstein Horst has been covered by up to $270 \mathrm{~m}$ of Tertiary sediments (Sonne 1969). Sedimentation continued until the Late Early Miocene (Burdigalian, c. $20 \mathrm{Ma}$ ) when the Nierstein Horst was uplifted and gradually denuded from its Tertiary sediment cover. The main uplift occurred as late as in the Pleistocene (Fuchs et al. 1983). Thus, erosion affected the Kisselwörth diatreme for a second time mainly within the last 2-3 Ma, a fact which might explain the rather fresh appearance of hornblende phenocrysts in the diatreme lapilli tuff.

On the Sprendlingen Horst c. $30 \mathrm{~km}$ east of Kisselwörth, i.e. on the corresponding eastern shoulder of the URG and northern continuation of the Odenwald Mountains with a tectonic history similar to that of the Nierstein Horst, the Middle Eocene (47 Ma) Messel Maar also contains pyroclastic rocks in its diatreme without any country-rock clasts younger than Rotliegend. This also applies to the Steinbuckel volcano, c. $8.5 \mathrm{~km} \mathrm{SSW}$ of Messel, where only contact-metamorphosed blocks of Rotliegend sediments have been found enclosed in a columnar jointed nepheline-basanite (e.g. Klemm 1910). For this volcano K-Ar dating indicates an age near the EoceneOligocene transition of c. $35 \mathrm{Ma}$ (Horn et al. 1972; Lippolt et al. 1974; Nickel et al. 1979). The lack of sediment clasts younger than Rotliegend above the mentioned diatremes documents that all Mesozoic sediments which had been deposited in this part of Germany, i.e. at the northern end of the URG south of the Hunsrück-Taunus fault and between the Mainz Basin in the west and the north-western Spessart Mountains in the east, have been eroded completely until the late Paleocene. Since then Rotliegend rocks formed erosional surface of the landscape.

For the Messel Maar we have to reckon a post-eruptive erosion of $380 \mathrm{~m}$ or more, as recently reconstructed by Büchel et al. (2010). Thus, the question arises if we have to expect more than $380 \mathrm{~m}$ of post-eruptive erosion for the Kisselwörth maar-diatreme volcano since it is $8 \mathrm{Ma}$ older than Messel.

\section{The Kisselwörth maar-diatreme volcano and the initial formation of the Upper Rhine Graben}

The Kisselwörth maar-diatreme volcano is $55.8 \pm 0.2 \mathrm{Ma}$ old, i.e. the volcano erupted near the Paleocene/Eocene boundary. This was well before the start of sedimentation indicating initial rifting in the southernmost URG between the Black Forest and the Vosges Mountains. There, terrestrial sediments are up to $52 \mathrm{Ma}$ old while limnic sedimentation started $46 \mathrm{Ma}$ ago. First brackish conditions established later around $45 \mathrm{Ma}$ (e.g. Grimm et al. 2011). This onset of an initial graben formation in the southern URG is predated by volcanic activity at Trois Epis near Colmar on the eastern flank of the Vosges Mountains. Here, by $40 \mathrm{Ar} / 39 \mathrm{Ar}$ single crystal laser dating of amphibole phenocrysts from an olivine-melilitite dyke an age of $60.9 \pm 0.6$ Ma has been determined. This predates first subsidence in this region by c. $15 \mathrm{Ma}$ (Keller et al. 2002; Wilson \& Downes 2006).

At the northern end of the URG subsidence started much later: First limnic sediments occurred at c. $35 \mathrm{Ma}$ and first brackish 2 Ma later (e.g. Grimm et al. 2011). Thus, the eruption of the Kisselwörth maar-diatreme volcano predates the start of subsidence-inducing rifting in the northern URG by c. $20 \mathrm{Ma}$ and the first subsidence at the southern end of the URG still by c. 10 Ma.

As far as we know today, the Kisselwörth diatreme is the only volcano that erupted on a fault which later became the western main fault of the URG. This implies that this fault enabled the rise of magma and was at the same time already under tension and consequently at least locally hydraulically active allowing explosive phreatomagmatic activity long before this fault became the western main fault of the graben. Of course, this also applies to the three volcanoes on the Eggish striking fault separating the Nierstein Horst from the Astheim Block.

\section{Implications and perspectives}

Wherever Pre-Tertiary rocks, i.e. mostly Rotliegend sediments (at the horsts of Hillesheim, Nierstein and Sprendlingen) but also rocks of the crystalline Variscan basement (e.g. the granitic Melibocus Mountain at the western edge of the Odenwald Mountains) and metamorphic Lower Devonian sandstones (i.e. the Taunus quartzite in the Hunsrück-Taunus Mountain Range) are cropping out today at the northern end of the URG, we find a considerable number of deeply eroded Paleogene volcanoes (basaltic dykes, plugs and diatremes). This suggests that many more of such eroded Paleogene volcanoes might exist below Oligocene and younger sediments of both the URG and the Mainz Basin as already assumed by Liebig and Gruber (2002).

A nice example for such a volcano is provided by the oil exploration drill hole Stockstadt-5 which penetrated "oilshale" at a depth of 1,709-1,723 $\mathrm{m}$ in the early 1950s (Straub 1955). This site is located c. $20 \mathrm{~km}$ south-east of the Kisselwörth diatreme in the URG. Comparing the log of the c. $60 \mathrm{~m}$ described by Straub (1955) with sediment cores that have been drilled in Tertiary maar lake deposits in recent years (e.g. Mingram 1998; Pirrung 1998; Fischer et al. 2000; Schulz et al. 2002; Pirrung et al. 2003; Goth and Suhr 2007; Kaulfuss et al. 2008; Lutz et al. 2010), it seems at least highly conceivable that drill hole Stockstadt- 5 by chance penetrated into the sediments of the early stages of a Late Middle to Upper Eocene maar lake (age assignment is based on palynological evidence analysed by V. Wilde and M. Hottenrott, personal communication, April 2012). Since this "maar-hypothesis" has been proposed for the Stockstadt-5 location, it turned out that the Stockstadt-5 cores are in parts still stored in the core repository of the ExxonMobil Production Deutschland $\mathrm{GmbH}$. With kind permission we 
recently studied and sampled the remaining cores and now can confirm this interpretation (to be published elsewhere).

Over a time span of possibly up to $10 \mathrm{Ma}$ this Eocene Stockstadt-5 maar-diatreme volcano was eroded down to its early lake beds when, due to the onset of subsidence of the northern URG, it discordantly was covered by younger sediments, i.e. Pechelbronn beds of Late Eocene (Upper Priabonian) to Early Oligocene (Lower Rupelian) age (c. $35 \mathrm{Ma}$ ). During that time not only the tuff ring and the syneruptive surface but also all juvenile volcanics in the tuffitic sediments surrounding the central argillaceous organic rich crater lake sediments as a coarse marginal facies and presumably also the upper parts of the diatreme tuff underlying these lake sediments had already weathered to clays as it is the case for the $44 \mathrm{Ma}$ old Eckfeld Maar (e.g. Pirrung et al. 2003, Lutz et al. 2010). Due to the load of the c. 1,700$\mathrm{m}$ thick Post-Eocene sediments, the "oilshale" facies has been compressed, dehydrated (today it consists of up to $90 \%$ of organic matter: Straub 1955) and the weathered volcanic clasts have been altered diagenetically. The sediments underlying this oilshale are by no means ascertained as in situ Rotliegend as Straub (1955) had supposed. Instead, these sediments are typical for the early stages of maar lakes when gravity induced event sedimentation (debris flows, turbidity currents) prevails (e.g. Fischer et al. 2000).

Like the Kisselwörth and the Stockstadt-5 maar-diatreme volcanoes such volcanoes are potential sources for radiometric or biostratigraphical age determinations and, considering their individual stage of erosion and lithostratigraphically relevant xenolithic clasts, they provide a time frame for the evolution of the regional palaeorelief since the Late Cretaceous.

Last but not least, for the planning of future research drill holes it seems of high interest to keep in mind the possibility of more or less eroded Paleogene maar-diatreme volcanoes, tuff rings and scoria cones hidden today by a sequence of up to 3,000-m thick younger sediments in the URG. This applies for drill holes for geothermal energy since the hydrology within diatremes filled with tuff and surrounded by a halo of fragmented country rock differs considerably from undisturbed country rock. It also applies if research drill holes are carried out with the aim of detecting crude oil resources, because it likewise should be taken into account that drilling into bituminous sediments of a former maar lake ends without any commercial value.

Acknowledgements We enjoyed various support from the "Ministerium für Bildung, Wissenschaft, Weiterbildung und Kultur Rheinland-Pfalz" represented by the "Generaldirektion Kulturelles Erbe Rheinland-Pfalz", the "Ministerium für Wirtschaft, Klimaschutz, Energie und Landesplanung Rheinland-Pfalz" and the "Ministerium des Innern, für Sport und Infrastruktur Rheinland-Pfalz". Harald Brock (Water Police Rheinland-Pfalz) and Ingo Braun (Police Rheinland-Pfalz, Helicopter Squadron Winningen) helped us unconventionally. Dieter Mertz (Johannes Gutenberg-Universität Mainz) and Paul Renne (BGC Berkeley Geochronology Center) provided an unpublished age determination, and Volker Wilde (Forschungsinstitut Senckenberg, Frankfurt a. M.) and Martin Hottenrott (Hessisches Landesamt für Umwelt und Geologie, Wiesbaden) provided palynological age assignments for the Stockstadt-5 oilshale. Michael Greller and Winfried Kuhn (both "Landesamt für Geologie und Bergbau Rheinland-Pfalz") assisted with first petrographic analyses and photos. Georg Meyer (Mainz) called one of us (HL) in 2003 to pay attention to the Kisselwörth locality and Gabriele Gruber (Hessisches Landesmuseum Darmstadt) provided information on the Sprendlingen Horst and the Messel Maar. Franz-Jürgen Harms (Hannover) drew our attention to the still existing cores from drill hole Stockstadt-5 and participated in their first examination. ExxonMobil Production Deutschland $\mathrm{GmbH}$ kindly permitted and supported our studies of these important cores. All this generous help and cooperation are gratefully acknowledged. Last but not least our sincerest thanks go to two anonymous reviewers for their critical and constructive comments and for linguistic corrections and to James D.L. White, Executive Editor, and Károly Nemeth, Associate Editor, for additional precious suggestions.

Open Access This article is distributed under the terms of the Creative Commons Attribution License which permits any use, distribution, and reproduction in any medium, provided the original author(s) and the source are credited.

\section{References}

Anderle H-J (1974) Block tectonic interrelationships between Northern Upper Rhine Graben and Southern Taunus Mountains. In: Illies JH, Fuchs K (eds) Approaches to Taphrogenesis. Schweizerbart, Stuttgart, pp 243-253

Baumann H, Illies JH (1983) Stress field and stress release in the Rhenish Massif. In: Fuchs K, von Gehlen K, Mälzer H, Murawski H, Semmel A (eds) Plateau uplift. The Rhenish Shield — a case history. Springer, Berlin, pp 177-186

Becker A, Schwarz M, Schäfer A (2012) Lithostratigraphische Korrelation des Rotliegend im östlichen Saar-Nahe-Becken. Lithostratigraphic correlation of the Rotliegend in the eastern Saar-Nahe-Basin. Jber Mitt oberrhein geol Ver NF 94:105-133

Boy J, Haneke J, Lorenz V (2005) Permokarbon. In: Landesamt für Geologie und Bergbau Rheinland-Pfalz (ed) Geologie von Rheinland-Pfalz. Schweizerbart, Stuttgart, pp 73-137

Boy JA, Haneke J, Kowalczyk G, Lorenz V, Schindler T, Stollhofen H, Thum H (2012) Rotliegend im Saar-Nahe-Becken, am TaunusSüdrand und im nördlichen Rheingraben. In: Deutsche Stratigraphische Kommission (ed) Stratigraphie von Deutschland X. Rotliegend. Teil I: Innervariscische Becken. Schriftenr Dt Ges Geowiss 61:254-377

Büchel G, Schaal S, Harms F-J, Pirrung M (2010) Rekonstruktion des Messel-Maarvulkans. In: Hoppe A, Röhling H-G, Schüth C (eds) GeoDarmstadt2010. Geowissenschaften sichern Zukunft. Frankfurt am Main und Darmstadt. Kurzfassungen der Vorträge und Poster, Schriftenr Dt Ges Geowiss, pp 68-119

Derer CE, Schumacher ME, Schäfer A (2005) The northern Upper Rhine Graben: basin geometry and early syn-rift tectono-sedimentary evolution. Int J Earth Sci (Geol Rundschau) 94:640-656

Deutsche Stratigraphische Kommission (ed) (2002) Stratigraphische Tabelle von Deutschland 2002

Deutsche Stratigraphische Kommission (ed) (2011) Stratigraphie von Deutschland IX. Tertiär, Teil 1. Oberrheingraben und benachbarte Tertiärgebiete. Schriftenr Dt Ges Geowiss 75

Deutsche Stratigraphische Kommission (ed) (2012) Stratigraphie von Deutschland X. Rotliegend. Teil I: Innervariscische Becken. Schriftenr Dt Ges Geowiss 61 
Dèzes P, Schmid SM, Ziegler PA (2004) Evolution of the European Cenozoic Rift System: interaction of the Alpine and Pyrenean orogens with their foreland lithosphere. Tectonophysics 389:1-33

Dürr SH, Grimm MC (2011) 1.2 Tektonische Übersicht. In: Deutsche Stratigraphische Kommission (ed) Stratigraphie von Deutschland IX. Tertiär, Teil 1. Oberrheingraben und benachbarte Tertiärgebiete. Schriftenr Dt Ges Geowiss 75:7-15

Falke H (1960) Rheinhessen und die Umgebung von Mainz. Slg Geol Führer 38. Borntraeger, Berlin

Fekiacova Z, Mertz DF, Renne PR (2007) The geodynamic setting of the Hocheifel volcanism, Part I: 40Ar/39Ar dating. In: Ritter JRR, Christensen UR (eds) Mantle plumes - a multidisciplinary approach. Springer, Berlin, pp 185-206

Fischer C, Gaupp R, Pirrung M (2000) Coarse-grained sediments from the Eckfeld Maar (Middle Eocene, Eifel, Germany): development of sedimentary facies. International Maar Conference, Daun/ Vulkaneifel. Terra Nostra 2000(6):118-122

Frenzel G (1955) Einführung in die Geologie und Petrographie des Katzenbuckels im Odenwald. Aufschluss 2. Sonderheft:48-56

Frenzel G (1975) Die Nephelingesteinsparagenese des Katzenbuckels im Odenwald. Aufschluss 27 (Sonderbd Odenwald):213-228

Fuchs K, von Gehlen K, Mälzer H, Murawski H, Semmel A (eds) (1983) Plateau Uplift. The Rhenish Shield - a case history. Springer, Berlin

Goth K, Suhr P (2007) Baruths heiße Vergangenheit. Vulkane in der Lausitz. Landesamt für Umwelt und Geologie, Dresden

Grimm MC, Wielandt-Schuster U, Hottenrott M, Grimm KI, Radtke G, Beiträgen M, von Berger JP, Ellwanger D, Harms FJ, Hoselmann C, Picot L, Weidenfeller M (2011) 5. Regionalgeologische Darstellungen. 5.1 Oberrheingraben. In: Deutsche Stratigraphische Kommission (ed) Stratigraphie von Deutschland IX. Tertiär, Teil 1. Oberrheingraben und benachbarte Tertiärgebiete. Schriftenr Dt Ges Geowiss 75:57-132

Horn P, Lippolt HJ, Todt W (1972) Kalium-Argon-Altersbestimmungen an tertiären Vulkaniten des Oberrheingrabens. I. Gesamtgesteinsalter. Eclogae geol Helvetiae 65(1):131-156

Houghton B, Wilson CJN (1989) A vesicularity index for pyroclastic deposits. Bull Volcanol 51:451-462

Illies JH, Fuchs K (eds) (1974) Approaches to Taphrogenesis. Schweizerbart, Stuttgart

Kaulfuss U, Lee DE, Lindqvist JK, Lutz H, Koziol M (2008) Comparison between two volcanic craters-Foulden Maar (South Island, New Zealand) and the Eckfeld Maar (Vulkaneifel, Germany). Geol Soc New Zealand, Misc Publ 124A:221

Keller J, Kraml M, Henjes-Kunst F (2002) 40Ar/39Ar single crystal laser dating of early volcanism in the Upper Rhine Graben and tectonic implications. Schweiz Mineral Petrogr Mitt 82:121-130

Klemm G (1910) Führer bei geologischen Exkursionen im Odenwald. Borntraeger, Berlin

Liebig V, Gruber G (2002) Das tertiäre Vulkanfeld Sprendlinger Horst (Südhessen). In: Niebuhr B (ed) GEO 2002. Planet Erde: Vergangenheit, Entwicklung, Zukunft. 1.-5. Oktober 2002 in Würzburg. Schriftenr Dt Geol Ges 21:224

Lippolt HJ, Todt W, Horn P (1974) Volcanism of the Rhinegraben: potassium-argon ages, local setting, petrology, and gravity anomalies. Apparent Potassium-Argon Ages of Lower Tertiary Rhine Graben Volcanics. In: Illies JH, Fuchs K (eds) Approaches to Taphrogenesis. Schweizerbart, Stuttgart, pp 213-221

Lippolt HJ, Baranyi I, Todt W (1975) Die Kalium-Argon-Alter der postpermischen Vulkanite des nord-östlichen Oberrheingrabens. Aufschluss 27:205-212

Lorenz V, Haneke J (2004) Relationship between diatremes, dykes, sills, laccoliths, intrusive-extrusive domes, lava flows, and tephra deposits with unconsolidated water-saturated sediments in the late Variscan intermontane Saar-Nahe-Basin, SW Germany. In: Breitkreuz C, Petford N (eds) Physical geology of high-level magmatic systems. Geol Soc, London Spec Publ 234:75-124
Lorenz V, Kurszlaukis S (2007) Root zone processes in the phreatomagmatic pipe emplacement model and consequences for the evolution of maar-diatreme volcanoes. J Volcanol Geotherm Res 150:4-32

Lorenz V, Zimanowski B, Buettner R (2002) On the formation of deepseated subterranean peperite-like magma-sediment-mixtures. J Volcanol Geotherm Res 114:107-118

Lorenz J, mit Beiträgen von Okrusch M, Geyer G, Jung J, Himmelsbach G, Dietl C 2010 Spessartsteine. Spessartin, Spessartit und Buntsandstein - eine umfassende Geologie und Mineralogie des Spessarts: geographische, geologische, petrographische, mineralogische und bergbaukundliche Einsichten in ein deutsches Mittelgebirge. Helga Lorenz Verlag, Karlstein am Main

Ludwig R (1864) Karten und Mittheilungen des mittelrheinischen geologischen Vereins. Geologische Specialkarte des Grossherzogthums Hessen und der angrenzenden Landesgebiete im Maasstabe von 1:50000. Section Darmstadt, pp 51-52

Lutz H, Kaulfuß U, Wappler T, Löhnertz W, Wilde V, Mertz D, Mingram J, Franzen J, Frankenhäuser H, Koziol M (2010) Eckfeld Maar: window into an Eocene terrestrial habitat in Central Europe. Acta Geol Sinica (Engl edn) 84(4):984-1009

Mingram J (1998) Laminated Eocene maar-lake sediments from Eckfeld (Eifel region, Germany) and their short-term periodicities. Palaeogeogr, Palaeoclimatol, Palaeoecol 140:289-305

Negendank J (1969a) Beschreibung einiger tertiärer Alkali-Basalte im nördlichen Oberrheingraben. Notizbl Hessischen Landesamtes Bodenforsch 97:283-295

Negendank JFW (1969b) Über permische und tertiäre Magmatite im Untergrund des Mainzer Beckens. Geol Rundschau 58(2):502512

Negendank JFW (1975) Permische und tertiäre Vulkanite im Bereich des nördlichen Odenwaldes. Aufschluss 27:197-204

Nickel E, Unter M, von Fettel M (1979) Odenwald. Vorderer Odenwald zwischen Darmstadt und Heidelberg. Slg Geol Führer 65. Borntraeger, Berlin

Noeggerath JJ (1842) Basalt-Durchbruch im bunten Sandstein bei Nierstein am Rhein. Archiv Min, Geognosie, Bergbau und Hüttenkde $16: 358-363$

Pflug R (1982) Bau und Entwicklung des Oberrheingrabens. Erträge der Forschung 184:1-145

Pirrung BM (1998) Zur Entstehung isolierter alttertiärer Seesedimente in zentraleuropäischen Vulkanfeldern. Mainzer naturwiss Archiv, Beih 20:1-117

Pirrung M, Fischer C, Büchel G, Gaupp R, Lutz H, Neuffer FO (2003) Lithofacies succession of maar crater deposits in the Eifel area (Germany). Terra Nova 15:125-132

Reischmann T, Beiträgen M, von Nesbor HD, Wimmenauer W (2011) 1.3 Tertiärer Vulkanismus. In: Deutsche Stratigraphische Kommission (ed) Stratigraphie von Deutschland IX. Tertiär, Teil 1. Oberrheingraben und benachbarte Tertiärgebiete. Schriftenr Dt Ges Geowiss 75:16-30

Richter-Bernburg G (1974) The Oberrhein Graben in its European and global setting. In: Illies JH, Fuchs $\mathrm{K}$ (eds) Approaches to Taphrogenesis. Schweizerbart, Stuttgart, pp 13-43

Röhr C (2013) Der Oberrheingraben. http://www.oberrheingraben.de/ index.htm

Sass I, Hoppe A (Projektleiter), Arndt D, Bär K (Bearbeiter), Fritsche JG, Kracht M (Kooperationspartner) (2011) Forschungsund Entwicklungsprojekt "3D Modell der geothermischen Tiefenpotenziale von Hessen". Abschlussbericht. Hessisches Ministerium für Umwelt, Energie, Landwirtschaft und Verbraucherschutz (HMUELV), Wiesbaden

Schäfer P (2012) Mainzer Becken. Stratigraphie, Paläontologie, Exkursionen [Field guide to the Tertiary basin of Mainz. Stratigraphy, paleontology, field trips]. 2. völlig neu bearbeitete Auflage. Borntraeger, Stuttgart 
Schindler T (2007) Geologie, Stratigraphie und Genese des permokarbonischen Saar-Nahe-Beckens. In: Schindler T, Heidtke UHJ (eds) Kohlesümpfe, Seen und Halbwüsten. Dokumente einer rund 300 Millionen Jahre alten Lebewelt zwischen Saarbrücken und Mainz. Pollichia Sonderveröffentl 10:4-37

Schmitt O (1974a) Zum Verlauf der westlichen Randverwerfung des zentralen Oberrheingrabens zwischen dem Rhein südlich Nackenheim und dem Main bei Rüsselsheim. In: Illies JH, Fuchs K (eds) Approaches to Taphrogenesis. Schweizerbart, Stuttgart, pp 254-269

Schmitt O (1974b) Zum Mainzer Becken gehörende Rotliegend- und Tertiärschollen. In: Schmitt O, Steuer A (eds) Erläuterungen zur Geologischen Karte von Hessen 1:25000. Blatt Nr. 6016 GroßGerau. Hessisches Landesamt Bodenforsch, Wiesbaden, pp 27-32

Schmitt O, Meisl S (1974) Basalt. In: Schmitt O, Steuer A (eds) Erläuterungen zur Geologischen Karte von Hessen 1:25000. Blatt Nr. 6016 GroßGerau. Hessisches Landesamt Bodenforsch, Wiesbaden, pp 32-34

Schmitt AK, Marks MAW, Nesbor HD, Markl G (2007) The onset and origin of differentiated Rhinegraben volcanism based on U-Pb ages and oxygen isotopic composition of zircon. European J Min 19:849-857

Schulz R, Harms F-J, Felder M (2002) Die Forschungsbohrung Messel 2001: Ein Beitrag zur Entschlüsselung der Genese einer Ölschieferlagerstätte. Z Angew Geol 4(2002):9-17

Schweizer V, Kraatz R (1982) Kraichgau und südlicher Odenwald. Slg Geol Führer 72. Borntraeger, Berlin

Sonne V (1969) Die Entwicklung des Alzey-Niersteiner Horstes seit Beginn des Tertiärs. Jahresber Mitt Oberrheinischen Geol Ver N F 51:81-86

Stapf KRG (1988) Zur Tektonik des westlichen Rheingrabenrandes zwischen Nierstein am Rhein und Wissembourg (Elsaß). Jahresber Mitt Oberrheinischen Geol Ver N F 70:399-410
Steuer A, ergänzt von Schmitt O, Sonne V (1974) Geologische Karte von Hessen 1:25000. Blatt Nr. 6016 Groß-Gerau. 2. überarbeitete Auflage. Hessisches Landesamt Bodenforsch, Wiesbaden

Stoltz K (1909) Geologische Bilder aus dem Grossherzogtum Hessen (Zweiter Teil: Rheinhessen). Beilage zum Jahresbericht des Großherzoglichen Ludwig-Georgs-Gymnasiums und der Vorschule der beiden Gymnasien zu Darmstadt. Otto, Darmstadt

Straub EW (1955) Über einen Fund von fraglichem Mitteleozän im Erdölfeld Stockstadt bei Darmstadt. Notizbl Hessischen Landesamtes Bodenforsch 83:220-227

Suhr P, Lorenz V, Goth K (2012) Maar-Diatreme volcanism and its post-eruptive subsidence. In: Arentsen K, Németh K, Smid E (eds) 4th International Maar Conference, a multidisciplinary congress on monogenetic volcanism. Auckland, New Zealand, 20-24 (2012) Geoscience Soc New Zealand. Misc Publ 131A:86-87

Suhr P, Goth K, Lorenz V, Suhr S (2006) Long lasting subsidence and deformation in and above maar-diatreme volcanoes - a never ending story. Z Deutsche Ges Geowiss 157(3):491-511

von Seckendorff V, Arz C, Lorenz V (2004) Magmatism of the late Variscan intermontane Saar-Nahe Basin (Germany): a review. In: Wilson $M$, Neumann E-R, Davie GR, Timmermann MJ, Heeremans M, Larsen BT (eds) PermoCarboniferous magmatism and rifting in Europe. Geol Soc, London Spec Publ 223:361-391

Wilson M, Downes H (2006) Tertiary-Quaternary intraplate magmatism in Europe and its relationship to mantle dynamics. In: Gee DG, Stephenson R (eds) European lithosphere dynamics. Geol Soc London Mem 32:147-166 